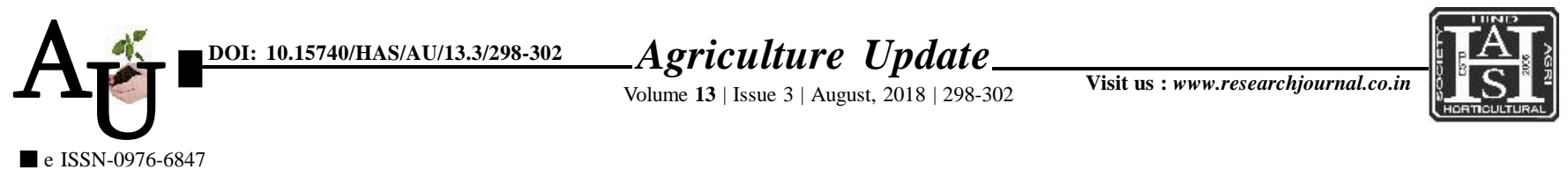

\title{
Research Article: Impact assessment of vocational training on mushroom production technology to farmers and rural youth at Krishi Vigyan Kendra, Tiruvallur district, Tamil Nadu
}

\section{R. Manimekalai, V.A. Vijayashanthi, P. Yogameenakshi, G. Satish and C. Tamilselvi}

Article Chronicle: Received :

12.05.2018;

Revised :

17.06.2018;

Accepted :

01.07 .2018

$\underline{\text { KEY WoRDS : }}$

Mushroom,

Vocational training,

Production

technology

Author for correspondence :

R. Manimekalai

ICAR-Krishi Vigyan

Kendra, Tirur, Tiruvallur

(T.N.) India

See end of the article for

authors' affiliations
SUMMARY : In Tiruvallur district, Tamil Nadu paddy crop is cultivated in 96000 hectares with the production of 3.9 lakh tonnes. In Tiruvallur district number of operational holdings under marginal $(0.00-0.99$ ha) category is 185059 and under small farmers category is 22572 . Effective utilization of farm waste in mushroom cultivation, as an allied agricultural activity under integrated farming system in doubling the income of farmers is being insisted by conducting skill oriented trainings to facilitate the complete knowledge of mushroom production activity on commercial scale in KVK, Tirur, Tiruvallur district. The present study was conducted to assess the impact of vocational training programme on knowledge about mushroom production in commercial scale and for self-employment at Krishi Vigyan Kendra, Tirur, Tiruvallur district Tamil Nadu. The results of the study revealed that knowledge gained from various lectures and demonstrations on mushroom production technologies was analysed by conducting pre and post evaluation tests and the results depicted that the post evaluation scores of gain in knowledge of various practices ranged from 64.00 to 98.00 per cent. The adoption of mushroom production on commercial scale by the participants was evaluated periodically and among the 37 participants of vocational training, 11 participants (29.72\%) have started mushroom production at cottage level and are practicing sincerely. Thus, it can be inferred that exposure to training had increased the knowledge of participants regarding mushroom production. The technical support and supply of oyster and milky mushroom spawn through KVK is being facilitated to the farmers and rural youth of Tiruvallur district.

How to cite this article : Manimekalai, R., Vijayashanthi, V.A., Yogameenakshi, P., Satish, G. and Tamilselvi, C. (2018). Impact assessment of vocational training on mushroom production technology to farmers and rural youth at Krishi Vigyan Kendra, Tiruvallur district, Tamil Nadu. Agric. Update, 13(3): 298-302; DOI : 10.15740/HAS/ AU/13.3/298-302. Copyright@2018: Hind Agri-Horticultural Society. 